\title{
Contribution to knowledge of calves and cows disorders in tie stalls housing system
}

\begin{abstract}
Diseases of calves in intensive farming are usually multifactorial etiology. The most important health problem in our farms high - producing dairy cows are separated diseases of the digestive and respiratory diseases. The occurrences of infectious diseases of various etiologies have great significance hygiene and microclimate, shelter and inadequate technological processes in education, particularly with regard to nutrition calves. The intensive rearing of calves requires continuous monitoring of the health status of calves and adequate implementation of prophylactic, hygienic and animal husbandry measures. Improving the health status of a positive impact on the results of own production and the standing welfare calves. Profilactic measures to prevent disease in high producing dairy cows, should primarily provide physiological activity of microorganisms in rumen contents at the time when dry cows went into lactation. Request a balanced diet meal according to the production, separation of older cows from cows are in milk, regular control of metabolic profile as one of the ways of controlling health, and to dry cows permit the provision of sufficient quantities of high-quality roughage, at least two weeks before calving. After calving, the amount of concentrated feed should be increased gradually (about $1 \mathrm{~kg}$ per day) until the peak of milk production. Presence of the pathogenic that causes different diseases in cows and calves has been monitored over the prolonged period of time on the dairy breed cattle. It has well been known that in large agglomeration numerous etiological factors have adverse effects on the health of the newborn calves, thus leading to considerable economic losses. Most often problems affecing calves were diareas and respiratory diseases. At our dairy farms were isolated folows bacteria: E.Coli, Pasteurella Multocida, Mannhemia Haemolitica, T. Pyogenes, Moraxella Bovis, Streptcoccus spp, Cl. Perfringens.
\end{abstract}

Keywords: calves, cows, disorders, health, tie-stalls housing system
Volume 3 Issue 6 - 2016

\author{
Jovan Bojkovski \\ Department for animal disease, University of Belgrade, Serbia
}

Correspondence: Jovan Bojkovski, University of Belgrade, Faculty of Veterinary Medicine, Belgrade, Bulevar Oslobodjenja 18, Serbia, Email bojkovski@vet.bg.ac.rs

Received: March 05, 2015 | Published:September 19, 2016
Abbreviations: DID, dermatitis inter digitalis; DD, dermatitis digitalis

\section{Introduction}

The intensive rearing of cattle includes a whole range of technological processes that should enable continuous production and optimal use of production capacity. In such circumstances, newborn calves have to adapt to different environmental factors, including diet. The technology of growing calves diet was initially based solely on feeding colostrum and then milk. After that, the food introduced other feed (hay, feed mixture), to a three-month milk completely excluded from the diet. Colostrum contains proteins, essential and not essential amino acids, fatty acids, lactose, vitamins, macro- and microelements. In addition, colostrum contains non nutritive ingredients like immunoglobulins, peptides, hormones, growth factors, cytokines, steroid hormones, thyroid hormones, nucleotides, polyamines and the enzymes. ${ }^{1-3}$ At high-yielding dairy cows metabolic disorders such as ketosis, fatty liver syndrome, puerperal paresis, rumen acidosis and laminitis, have been caused by many factors, such as unbalanced diet and inadequate breeding. ${ }^{4-10}$ The aim of this letter is to provide information on health status of calves and high-yielding dairy cows on farms with tie-stalls housing system.

\section{The health status of calves}

Neonatal calves are subject to cardio-respiratory and metabolic disorders that can be diagnosed in the early weeks of life. Practice has shown that calves individually develop the ability to consume colostrum, after milk. In these moments it includes the structure and function of their digestive organs. In the course of the colostrum period, colostrum changes in their composition. Colostrum has a role in the creation of passive immunity, but also has the ability to newly born calf supplies from the carbohydrates, lipids, proteins, mikorelemnts, vitamins, and other biologically active compounds. The content of active substances biochemic specific hormones, growth factors, cytokines, polyamines, nucleotides at neonatal calves ordered causes biological effects. Insulin-like growth factors (IGF), which shows a high value in colostrum can calves to stimulate the development of the digestive system in particular its function in the neonatal period. Establish the concentration of growth factors and hormones in the greatest secretion of colostrum before parturition. ${ }^{1,11}$ If colostrum store first 24hours after calving leads to an increase in NEFA, where the concentration of cholesterol, essential fatty acids, pro-vitamin decreases ${ }^{12}$ During the first power concentration is greatest then after the first and second day of a decline in their concentration. ${ }^{11}$ Diseases of calves in intensive farming are multifactorial etiology. The most frequent and the most important health problems on our farms stand out disorders of the digestive and respiratory.13,14 The occurrence of infectious diseases of different etiologies have great significance unfavorable hygienic and microclimate condition accommodation and inadequate technological procedures in raising calves. The intensive rearing of calves requires constant control the health status of calves and adequate implementation of prophylactic hygiene and animal husbandry measure. Improvement health condition positively 
affects the performance and the state of well-being calves. Welfare taken with regard to housing conditions usually endangers inadequate ventilation, air velocity and temperature of the air, as well as exposure to live agents. In addition to data on housing conditions for a complete picture of the state of well-being are taken into account nutrition and specific control procedures, such as a power mode or refusal calves. Analysis of the potential risks for the benefit of a farmer indicates more possible causes already present health and other problems in calves as well as the problems that may occur in the future. ${ }^{13,15}$

\section{The health status of cows}

Ketosis is a metabolic disorder that occurs in high-yield dairy cows, most often in the third or fourth lactation, during the first weeks after calving and in early lactation. The occurrence of ketosis contributes more factors, but the main reason besides physiological low blood glucose in ruminants and insufficient energy intake at a meal, which is needed for the early stages of lactation. Glucose in the blood is the most important energy source for the cow. However, glucose can easily and rapidly ferment in the rumen. When there is not enough energy to mobilize fat reserves and accumulate ketone bodies in excess in amounts, which may cause disturbances in the body. In such cases, there are signs of ketosis: loss of appetite, weight loss, reduction in milk production, but in severe cases and nervous symptoms. Understanding the physiological and metabolic processes, as well as the peculiarities of metabolism in ruminants, which occur in pregnancy and lactation, it is particularly important for the science and practice of nutrition, given that food is just a medium through which in normal circumstances, and the body supplies the necessary nutrients to settle increased needs during the aforementioned physiological conditions. Therefore, the task of feeding a high-yield dairy cows to ensure, above all, good health and condition of animals, lactation for a period of about 300 days, as well as the growing number of lactation during operation, the maximum amount of milk optimal chemical composition, and bringing healthy and vital during a year. To high-dairy cows could respond to these requirements, conditions for its keeping, care, health, nutrition and above all, must be maximally adapted to the needs of the organism (meal aligned to milk production) and pushed to the limits of the ideal, to the extent possible modern cattle breeding. It is known that those errors that occur in the last third of pregnancy become clearly visible and marked during the early puerperium. With metabolic aspect therefore, ketosis is a disorder of metabolism of carbohydrate and fat, where in the blocked $\beta$-oxidation of fatty acids, and the process is stopped at the level of acetyl-CoA. A decisive crossroads of many roads in inetrmediar metabolism, even in flows re-synthesis of glucose and fatty acid degradation, is oxaloacetate. Since the process of synthesis of glucose peak is activated, the largest amount of oxaloacetate is' seized 'and' implemented " way of gluconeogenesis. This results in the accumulation of large amounts of acetyl-CoA, which cannot be completely oxidized, and there is a joining of two molecules of acetyl$\mathrm{CoA}$ and ketone bodies synthesis of the first, acetoacetic acid, and from it, and $\beta$-hydroxybutyric acid acid and acetone. Synthesis of ketone bodies, within the physiological range, occurs in healthy animals intensity of $25 \mathrm{~g} / \mathrm{h}$. Most of the tissue is able to use ketone bodies as an energy source, and the degree of their decomposition is proportional to the concentration in the blood to levels of $3.44 \mathrm{mmol} / \mathrm{L} .{ }^{16}$ Ketone bodies are in excess accumulates in the blood and then excreted in urine and milk, and partly through the lungs. Secretion of ketone bodies organism that is already in an energy deficit, in addition to losing a large amount of energy, given that the ketone bodies still tied around $75 \%$ of the energy value of fat. ${ }^{8,9,17,18}$ Summarizing the foregoing considerations, it is necessary to focus the attention of the diet that emphasizes its importance in the prophylaxis and treatment of metabolic disorders. Be sure to take these conditions (subclinical ketosis) can be monitored and regular monitoring of parameters of metabolic profile, which included some analysis of the assessment of the functional status of liver cells (plasma, glucose, AST, total bilirubin, and albumin) and a valid interpretation of the received analysis, it is possible to liver hepato-protective protect and prevent ketosis. ${ }^{89}$ Meals for lactating dairy cows are based on the use of a large number of different nutrients and meals, in relation to the dominant type of nutrients, can be cumbersome and semi concentrated. When deciding which type of meal to determine the factors that should be kept in mind as before productivity of all the animals, but also the possibility of providing adequate nutrients, as well as its price. Bulky meals are usually much cheaper, or support the production of 10-12liters of milk. In the case of higher milk yield, which is the tendency of keeping dairy cows, it is necessary to provide the cow material substrate from which will be made biosynthesis of milk, which means the application of the diet of the more expensive and higher quality concentrate feed. ${ }^{8} \mathrm{An}$ important moment in the planning of feeding cows the harmonization of relations bulky and concentrated in the ration, especially in the dry period and early lactation. High yielding cows required usage of greater amounts of concentrated feed and it is recommended to avoid forages with high water content (silage with less than $25 \% \mathrm{DM}$, cellulose feed). Too much voluminous of these nutrients, or a small amount of energy and nutrients per unit mass, makes cow unable to consume a sufficient amount to meet their basic needs. The quality hay (meadow, legumes etc.) may be offered at will. In addition, concentrated part of the meal, adapted to production status, should be divided into several parts in order to achieve a more even the arrival of carbohydrates in the rumen and their interpretation under the influence of micro flora. This is especially important in order to avoid or significantly reduce the occurrence of rumen acidosis. This way of feeding avoid the emergence of " peak ", glycemic, which is inevitable in the nutrition of high-yielding cows fed mainly concentrated fertilizers. ${ }^{8}$ A particular problem in planning meals represents the harmonization of relations of some kind of carbohydrate that the animal enters a meal. It is necessary to emphasize the importance of cellulose, but also starches as precursors of propionic acid, a key mediator of gluconeogenesis, while the share of easily digestible carbohydrates, although they represent " instant energy, " carries with it the constant risk of metabolic disorders. The meal made up of $32.2 \%$ of hay, silage $11.1 \%, 21.8 \%$ of root nutrient, and $34.9 \%$ concentrated feed ensures optimum milk yield and satisfactory state of health. Increasing the share of concentrated feed at $45 \%$ increased milk yield by $22 \%$ in the first third of lactation. In line with the traditional way of eating cows, recommend related energy originating from the bulky and concentrated feed, the level of $55: 45,75: 25$ and $94: 6$ in the first, second and third period of lactation, which in the appropriate indigenous provides optimal conditions milk yield and milk quality. ${ }^{8}$ The parameter should be taken into account is the daily food consumption, which is especially a problem in terms of stress and drastic physiological changes during late pregnancy, parturition and early lactation. In general, meals should be tasty and attractive for a cow, preserved organoleptic properties, hygienic and free of harmful impurities.. The mechanism of control meal includes current control (the rumen $\mathrm{pH}$ content, the amount of volatile fatty acids and levels of certain hormones such as insulin, glucagon, gastrin) and long-term control of consumption (physiological state, 
the status of nitrogen, factors external environment, photoperiodical and seasonal differences, the level of production and the overall needs of the energy). There are also the body weight of cows, genetic markers, health, competitive higher priority (thermoregulation), as well as factors related to palatability and lure meal. ${ }^{8}$ In heavy conditions (unbalanced diet in prepartal period) comes to depositing excess nutrients in the body and so-called depots - fatty liver syndrome. Under conditions of energy deficit and the consequent rapid mobilization of fat from the depot, which is common in fat cows, and too quickly the accumulation of free fatty acids in the blood and their deposition in the liver. The high concentration of free fatty acid in blood conditional decrease appetite, and reducing the consumption of animal reacts, which then leads to an energy deficit when thin cows rapidly even with a possible lethal accumulation occurs outcome. Liver fatty acid in the form of lipid infiltration and degeneration of hepatocytes. With such an additional burden on the liver loses its functional activity which contributes to the appearance of ketosis, or aggravation of reparation and restitution processes in hepatocytes, for complete recovery is realized only when the liver rid of excess fat, which is a slow and long process. "Fatty liver syndrome" is therefore an example of the energy imbalance caused by excessive consumption of food/energy and increased deposition of fat in hepatocytes, but also in other tissues such as subcutaneous tissue, and often uses the term "fat cow syndrome". When cows during the last lactation period and dry period receives high - energy meals leads to fat storage. This situation has an impact on the occurrence of severe calving of placental retention, or even the appearance of metritis. When the exhibit loss of appetite, resulting accelerated mobilization, fat from the body's reserves and, consequently, increased formation of ketone bodies. Common to all herds with this diet is to have fertility problems, as reflected by long service periods and reduced conception. In heard with long calving interval, usually at the time of calving cows have fattening condition too. Ketosis is then one of the secondary diseases that occur in such conditions, but which requires a particular therapeutic treatment (parenteral application of gluco-corticosteroids and glucose) which further economically burden the production of milk. It is therefore necessary metabolic profile as a measure of the detection of subclinical ketosis, conducted at least twice a year, in late pregnancy and early lactation. ${ }^{8,9,19-21}$ The objectives to be pursued in order to prevent fatty liver syndrome, the provision of adequate, not overly energy-rich meals, in order to prepare the rumen microorganisms, the meals that will be following in lactation, giving dry cows, $2-3 \mathrm{~kg}$ of these nutrients, two weeks before calving. After calving concentrate should be increased by $1 \mathrm{~kg} /$ day, to achieve peak production. It is necessary to give $2-4 \mathrm{~kg}$ of hay daily, in order to reduce fluctuations of microorganisms, which can occur during the change in the meal, as a result of the high demand in the early period of lactation. It is desirable to maintain the interval between calving for a period of 12 to 13 months, or years/calf, separated by dry cows from dairy cows, with the aim to reduce the potential for "fatty liver syndrome" and to maintain a high lactation. ${ }^{8,9,20}$ It is known that there may be the need of a number of inseminations and prolonging the cycle between calving in cows fed with a high content of easily soluble protein ( $17 \%$ protein with $75 \%$ solubility), which is also called syndrome of infertility. As a result of such a diet high contents of ammonia in the rumen, which is excreted through the urine or via milk. The increase in the content of ammonia nitrogen in milk, urine and body fluids, is a result of the need for an increased number of inseminations. Jon ammonia in excess operates toxic to the embryo and prevents the implantation and development of the fetus.
Recommendations should relate to the reduction of accumulation of ammonia nitrogen, as a result of eating excessive amounts of protein. It is therefore necessary to avoid food with high amounts of protein, especially easy soluble protein, and provide the necessary amount of energy (in conformity ratio of protein: energy), which is the main objective norms compliant food. ${ }^{7,8}$ In addition to the importance of eating well-balanced meals are very important needs of microorganisms in the rumen contents. The needs of microorganisms in the amino acids and energy, as well as the range of $\mathrm{pH}$ in the rumen (which is physiologically from 5.5 to 6.8 ) should be taken into account in determining the best meal at high-yielding dairy cows. Acidosis due to accumulation of lactic acid in an excess fermentation is a disorder that is manifested in several forms, depending on the amount of imbalance. Basically, rumen acidosis occurs when feeding highly soluble carbon-hydrated nutrients. When the hay are broken down in the rumen, under the influence of microorganisms, the fall in $\mathrm{pH}$ from 6.8 to a value of about 5 inhibits certain groups of microorganisms (protozoa and gram-negative bacteria) and facilitates the development of those bacteria that require an acidic environment. If the animal is long on such a diet or meal energy, acidosis can cause damage to the lining of the rumen, allowing bacteria formation ruminitis. Complications arise as peritonitis, liver damage caused by switching of infectious agents in the blood stream, and consequently laminitis. Less important symptoms may arise as a simple refusal of food, which is subsequently adjusted to overeating, which may result in atony of the rumen, and the accumulation of excess fluid in the rumen. This together with an excess of fluid in the rumen results in signs such as dehydration, decreased appetite, reduction in milk production, reducing rumen contractions, sometimes dry dung, which may continue in the diarrhea. The aim should be to ensure a balance between the prevention of microorganisms. This can be achieved by feeding certain amount of food given to an equal intervals, avoiding sudden changes to the high-energy rations. Adequate amounts of concentrate and high quality roughage are necessary to achieve these objectives. ${ }^{8,9,22}$ As a consequence of the transport of mineral substances (or inadequate intake or increased their loss) is the appearance of puerperal paresis or hypocalcemia or milk fever. Older cows have a reduced level of absorption of calcium, as well as reduced mobilization of calcium from the bones. In relation to the needs of the fetus for minerals and produced milk, these two facts lead to reduced opportunities to newly calved cows form physiological reserves of calcium in serum. In cows with milk fever, decrease calcium levels (hypocalcemia) manifested with general weakness, "fall off my feet," sometimes coma and mortality, if the resulting disorder is not treated in a timely manner. In cows with milk fever manifested and disorders in the form of indigestion and reduced absorption of nutrients. Factors that contribute to the occurrence of hypocalcemia are: reducing opportunities for older cows to quickly mobilize calcium from the bones or absorption from the small intestine, a decrease in appetite that occurs after calving further deepens this problem. ${ }^{8,9,20}$ We must therefore allow just before calving physiological consumption, flow and absorption of nutrients. It is known to regulate the maintenance of physiological levels of calcium, calcium homeostasis is strictly regulated with several mechanisms (kidneys, skeletal system, with the participation of thyroid gland hormones and vitamin D). Imbalance mineral matter immediately after calving and in older high-producing dairy cows, most often leads to so-called typical hypocalcemia or infrequently and so atypical parturient paresis in which the level of phosphorus domintan drop, and/or even less frequently recumbent cow syndrome. Prophylaxis and recommendations in this regard 
related to the increased attention in the way of keeping and feeding in the dry period. Most metabolic diseases occurs at the end of pregnancy or in early lactation, and are caused by the troubled relations of energy and minerals in the diet. So have appeared recently and of the "syndrome of infertility" in feeding high protein diets in the dry period, and which affects negatively in the later stages of lactation or as a problem following conception. ${ }^{7,8}$ Therefore up to three weeks before calving highly pregnant cows should gradually translate and get used to the ration of lactating cows, in order to rumen microorganisms "prepare and develop" the conditions for a new installment, as well as meal before drying off adding an equal relationship or even something more phosphorus than calcium, in order to timely launched mobilization calcium from reserves. ${ }^{4,5}$ It is also possible and prepares acidic or anionic meals. Such a meal reduces the incidence of milk fever and by a certain acidification that maximizes ionization of calcium in the intestines and improves its absorption and probably improves the ability to transport and the adoption of calcium from the bones. Another measure that can be taken is to add a meal of vitamin D. This is a good method if the time of calving knows exactly, but if these meals provide for a prolonged period can cause poisoning in vitamin $\mathrm{D}$. Thus, the addition of vitamin $\mathrm{D}$ to frequent benefits cannot be recommended, especially injectable preparation, because vitamin D has a structure and catabolism similar to steroid hormones, which can have a negative effect on the situation heaptocit, who are otherwise significantly damaged in high-producing dairy cows fed unbalanced diets. An important moment in the planning of feeding cows the harmonization of relations bulky and concentrated work meals. Extremely high needs cows with high milk production require usage of greater amounts of concentrated feed, with a consequent reduction in crude fiber content in the diet. Because too voluminous such nutrients, or a small amount of energy and nutrients per unit weight, the animal is unable to consume a sufficient amount for the settlement. In this respect we should bear in mind that: a meal poor in calcium weeks before calving intensifies metabolism of calcium, to provide meals with adequate amounts of calcium immediately after calving creates favorable conditions to maintain physiological levels of calcium, as well as the need to provide sufficient and/or increased amounts of magnesium, phosphorus and vitamin D. Meals with a low amount of calcium a few weeks before calving prevent puerperal paresis prepartal activation of bone system and the intestinal canal. It is recommended that two weeks before parturition benefits meal with less than $80 \mathrm{~g} \mathrm{Ca}, \mathrm{P} 60 \mathrm{~g}$ and about $35,000 \mathrm{IU}$ of vitamin $\mathrm{D}$. It is very important to solve the issue choices nutrient poor in calcium and assemble an adequate meal which settles other needs of the animals in the last weeks of the dry period. Hay and silage are in this case not suitable because of the abundance of calcium and nutrients as elections are used potatoes and by-products of potatoes, other root-tubers feed, brewery spent grain, meal of maize germ, bran and corn meal. Immediately after calving, when it is necessary to offer animals a meal rich in calcium, the account can come beet pulp, hay and silage (grass, legumes), as well as the addition of mineral nutrients as a source of calcium. Practical lack of such a diet is a necessity to ration after calving is changing gradually, as it is known that sudden changes in ruminant's meal can cause a disorder of micro-organisms and lead to indigestion. Compare meals applied in a series of trials aimed at testing the possibilities of preventing puerperal paresis, it was observed that increasing consumption in the dry period caused a greater incidence of the disorder. Cows with higher consumption prepartal demonstrated the labile calcium homeostasis and require additional treatment, while the animals that are fed small amounts of food, spontaneously recovered. Pursuant to the results, it is recommended that consumption in prepartal period increased by about $20 \%$ compared to the need to sustain life. Practical experience shows that on some farms there are cases of puerperal paresis without express hypocalcemia, or with severe hypomagnesaemia. Magnesium deficiency shows up as a significant factor in the formation of puerperal paresis, disrupting calcium homeostasis, because it reduces the level of calcium mobilization after calving, and considering that the mobilization of magnesium from the depot significantly slower than the calcium mobilization, are often the symptoms that resemble pasture tetany. The ratio of calcium and phosphorus in the diet significantly affect intestinal absorption, bone mobilization of calcium and the amount of available, but the recommended ratio of $\mathrm{Ca}$ : $\mathrm{P}$ of 1 : 1. One of the options to prevent the appearance of puerperal paresis is changing the relationship of anions and cations in the meal. Increase acidogenic minerals compared to Alcalogenic a meal before calving has a positive effect on turnover of calcium. ${ }^{8,9}$ Laminitis represents aseptic inflammation of the hoof dermis. As the causes of the disease in addition to mechanical overload hoof statements are toxic and causes, and the formation of the allergic basis. ${ }^{20,23}$ Longer giving easily digestible concentrate feed, to acidosis in the rumen, sudden change of food, especially food green barley, oats, fresh trimmed young legumes and feeding moldy food, can lead to the development of laminitis. Laminitis is often the result of influence of a large number of factors, such as metabolic and gastrointestinal diseases, birth stress, mastitis, metritis, without docking or rugs with very little, without the possibility of movement, fattening, management, and poor nutrition. The meal, which leads to acidosis leads to laminitis, it is difficult to correct when the highest percentage of nutrients in a meal consisting of carbohydrate substances. It is believed that the vasoactive substances (histamine) that enter the bloodstream of the rumen to damage the hoof dermis. Metabolic disorder is caused by low rumen $\mathrm{pH}$ content and chained comes to the pathophysiology that ultimately result in ischemia dermis hooves and clinical symptoms of laminitis (disposal leg because of the pain, and sometimes forced lying). Believe that besides histamine and bacterial endotoxins, lactic acid and other biologically active substances in the etiology of this disease. The amount of concentrated feed that the cow enters a meal, sometimes low rumen $\mathrm{pH}$ content and appearance of locomotor disorders, have a common etiopathogenetic background..$^{8,9,13,23,24}$ There are claims that the presence of mycotoxins (fungi damaged food) can be involved in the etiology of laminitis. Aflatoxins each very present and most mycotoxins, leading to poor growth and poor reproduction, increased susceptibility to injury, reduced consumption and poor cellular and humoral responses of the immune system..$^{25}$ In a study in order to determine the relationship between aflatoxin contaminated feed, laminitis, and fertility observed lesions in the regions and hoof tarsus that led to lameness in 45 of a total of 300 high-yield dairy cows Holstein cows. In 27 cows are identified cystic ovaries, while the 10 cows had cystic ovaries with clinical equine cases. From this study came to the conclusion that aflatoxins enter the food (hay, alfalfa and concentrate) caused lameness (subclinical laminitis) and reduction fertility. Estasblished amount of aflatoxin B1 (AFB1) in the hay was 4.1, 2.7 in alfalfa and concentrated feed 5.4ppb. Aflatoxin M1 (AFM1) is a metabolite of AFB1 contaminated feed and can be found in milk and milk products. ${ }^{25}$ To make milk production and keeping dairy cows be profitable, it is necessary, with respect to all other prophylactic and zoo-technical measures, ensuring continuous animal feed quality, hygienic food meal balanced in all the necessary nutrients, in accordance with the accepted and scientifically verified recommendations. 
Dermatitis interdigitalis is a bacterial inflammation of the heel and of the skin between two fingers and the area of the pads, very alike to Dermatitis digitalis, the only difference is the area where lesion appears. ${ }^{26,27}$ In the previous years, Dermatitis interdigitalis was the most common problem of hoofs disease in the region. ${ }^{28-30}$ Dermatitis digitalis (Mortelar's disease) is a bacterial infection that causes ulcerative skin inflammation in the area above the back hoof part and, less frequently, above interhoof scope of the front hoof part. The first time it was described in 1974, in Italy by Cheli \& Mortellaro. Dermatitis interdigitalis (DID) and Dermatitis digitalis (DD) are two extremely contagious diseases of cattle hoofs of multicausal etiology. We studied incidence of Dermatitis Interdigitalis and Dermatitis Digitalis at the dairy farms during 2010-2011. ${ }^{31}$ During the observed period, diagnosed DID ranged from $49,40 \%$ at the farm" 03 ",(during the first round in 2010 .), to $81,79 \%$ at the farm " 07 " (during the same round), while the number of diagnosed DD varied between $13,50 \%$ at the farm " 01 " to $47,73 \%$ at the farm " 03 ", (also during the first round in 2010). Very high results of incidence these two 245 diseases caused increased occupation in the introducing of preventive technological measures and actions in order to suppress these contagious hoofs diseases. At the farm "07" DID was reduced to $63,71 \%$ in the second round in 2010, while at the farm "03" DD was reduced to $23,32 \%$, also during the second round in 2010. Accomplished reduction in number of infected animals by these two hoofs diseases have resulted in less management and competent services care in technological measures and procedures that had been introduced. Situation at both farms deteriorated in the first round in 2011. At the farm "07" DID was $75,08 \%$ and at the farm " 03 " DD was $32,41 \%$. Increased technological measures and disinfection procedures at these two farms resulted in: DD reduced to $28,99 \%$ at the farm " 07 " (in the first round in 2010.) and to $28,71 \%$ in the second round in 2010 , but in the first round in 2011 it increased to $35,90 \%$. DID disproportionately increased in relation to DD at the farm " 03 ", from $49,40 \%$ (in the first round in 2010.) to $72,42 \%$ in the second round in 2010 , and disproportionately reduced compared to DD to $66,66 \%$ in the first round in 2011. Negative results in the first round in 2011 were caused by the formal approach to recommended prevention measures and procedures, so that it motivated management and competent services to control implementation of prescribed measures and procedures. Serious approach to prevention measures and procedures resulted in reduction of diagnosed DID to $27,92 \%$ at the farm " 03 " and DD had been reduced to $67,76 \%$ at the farm " 07 " in the second round in 2011. During the mentioned period, diagnosed DID didn't follow downward trend at the farm " 03 ", on the contrary increased to $76,24 \%$, while DD fell to $25,49 \%$ at the farm " 07 ". At the farm " 01 " diagnosed DID constantly grew in all four rounds in 2010 and 2011. It was very high - 68,82\% - in the first round in 2010 and after that it permanently increased over $71,10 \%$ in the second round in 2010 and in the first round in 2011. DD grew from acceptable $13,50 \%$ in the first round in 2010 , to $25,87 \%$ in the second round in $2010,29,71 \%$ in the first round in 2011 and then it minimally reduced to $28,01 \%$ in the second round in 2011. These results can be explained by high fluctuation of workers at the mentioned farm, so prevention measures and procedures that had been recommended couldn't be conducted properly. Similar variation of incidence of diagnosed DID and DD were noticed at the farms " 02 ", " $04 ", " 05$ " and " $06 "$, but the results are non-significant. These four farms had shared all PKB Corporation problems: high fluctuation of workers, incomplete and nonfunctional infrastructure elements, omission of prescribed preventive measures and procedures, under educated production stuff about importance of preventive measures and procedures in livestock production. T-Test refers to testing the statistical significance of differences between the two means. The resulting difference between the two means is divided by standard deviation of this difference. The meaning of the symbols in the above t-tests: $\mathrm{Mu}$ - the difference; $\mathrm{N}$-number of cases; Mean-mean, St.Dev-standard deviation; Df - degrees of freedom in the statistical procedure; T-test was calculated experimentally; $\mathrm{P}$ is the $t$ value from the table to be taken for a given degree of freedom. ${ }^{31}$

\section{The pathogenic causes of disease in dairy cows}

The presence of pathogenic microorganisms in calves and dairy cows was investigated on farms of high-yielding cows. We took rectal and nasal swabs. In microbiological laboratory was isolated the pathogenic microorganisms and in individual cases determined the adequate therapy. Also, we investigated the effect of different housing conditions and care for the presence of certain pathogenic microorganisms. High-yielding cows during 305days of lactation are constantly exposed to various factors that directly or indirectly affect the health of the animals. This situation imposes the need to constantly control the state of health, so that animals could survive in the production minimum five lactations. Today's technology of growing and keeping cattle in large agglomerations causes many health problems. In the calves were isolated bacteria's pathogens: Escherichia coli, Pasteurella multocida, Mannhemia haemolitica, Truperella pyogenes, Moraxella bovis, Steptococcus sp, Clostridium perfringens type $B .^{32}$ Diarrhea is a complex syndrome from the etiological point of view, developing as a result of environmental and nutritional factors and combination of diverse infectious agents. Based on examination of the rectal swabs, E. Coli was isolated on a dairy breed cattle farm during the wintertime. According to the susceptibility test, appropriate antibiotic therapy was applied. . $^{33,34}$

Inappropriate passive immunity, exposure to adult animals, poor ventilation, overcrowded housing facilities, wide temperature variations, transportation and other stress factors may lead to development of respiratory infections. Group calf housing contributes to spreading of infections with inhalation being the major transmission pathway of respiratory infections. Clinical signs of pneumonia include nasal discharge, elevated body temperature, and decreased appetite and breathing disorders. Administration of antibiotics is necessary however, the results are frequently disappointing. Complete recovery is rare in calves with chronic respiratory infections. Due to the significance of the respiratory system diseases for growth and future productivity of dairy cows, early identification of causes and treatment are of the utmost importance, with elimination of the risk factors being the imperative. ${ }^{9,35}$ The most frequent bacterial infections of the respiratory system in calves on the dairy farms are caused by the following bacteria: Pasteurella multocida Mannheimia haemolytica, Trueperella (Arcanobacterium) pyogenes. In very young calves, Streptococcus Pseudomonas aeruginosa and Haemophilus somni are of the highest importance. ${ }^{11,31}$ The following bacteria were isolated on the high production dairy farm: Pasteurella multocida, Mannheimia haemolytica, Pasteurella spp., Histophilus somni, Haemophilus spp., Trueperella (Arcanobacterium) pyogenes, Nocardioform microorganisms, Pseudomonas aeruginosa, Salmonella Enteritidis, Salmonella Typhimurium. Synergistic bacterial and viral actions are also important for onset of respiratory diseases in calves, particularly in overcrowded facilities with poor microclimate conditions (low temperature and high humidity, high concentration of ammonia and draft) as well as in animals with impaired immunity. Infection of airways is a constant problem associated with seasonal flaring, particularly on the farms where zoohygienic measures are not 
properly performed..$^{35}$ Welfare of calves related to housing conditions is most frequently compromised by inadequate ventilation, air flow and temperature as well as exposure to pathogenic microorganisms and parasites. In addition to information on housing conditions, in order to obtain full picture on welfare of the animals, feeding and certain management procedures must be also taken into account, such as method of watering or weaning of calves. Analysis of potential risks for welfare of farm animals points out to the possible cause of already present health-related and other problems in calves, as well as to the problems that may appear in the future. ${ }^{15}$ Viruses, bacteria and mycoplasmas (Mycoplasma bovis) are implied as the most common causes of diseases of the respiratory organs ${ }^{35}$ Pathogenic effects of viruses and mycoplasma favor subsequent pathogenic effects of the bacteria. Bojkovski et al. ${ }^{13}$ reported that the most common isolates from the nasal swabs obtained from calves affected with respiratory infections were the following: Pasteurella multocida, Mannheimia haemolytica (Pasteurella haemolytica), Trueperella (Arcanobacterium) pyogenes, Haemophilus spp., as well as Klebsiella pneumoniae. Investigations presented in the paper confirmed earlier conclusion that Pasteurella multocida was the most predominant cause of respiratory diseases in calves originating from high production tie-stall housing dairy farms. Namely, it has been known that calves are prone to cardiorespiratory and metabolic disorders that may be diagnosed as early as during the first several weeks of life. The reason for the above lies in incompletely formed organisms of the newborn calves, and accommodation to the extrauterine way of life must be rather fast in conditions of the contemporary beef cattle production. ${ }^{9,35}$ Calf vitality may be influenced by mistakes made in management of pregnancy, particularly those related to feeding of cows during the last third of pregnancy. ${ }^{9}$ Etiology of calves diseases in intensive breeding is most commonly multifactorial, with respiratory diseases being the most important health-related problems on our farms. On a tie-stall housing farm the following bacteria were isolated in calves within a calendar year: Pasteurella multocida, Mannheimia haemolytica, Pasteurella spp, Histophilus somni, Haemophilus spp, Trueperella (Arcanobacterium) pyogenes, Escherichia coli, Klebsiella pneumoniae, nocardioform microorganisms, Pseudomonas aeruginosa, Salmonella Enteritidis, Salmonella Typhimurium. Intensive breeding of calves requires continuous monitoring of their health status and appropriate application of veterinary-prophylactic, hygienic-sanitary and zootechnical measures. Presence of the infectious bovine keratoconjunctivitis was evidenced in 4month old calves, kept in the stalls. Ocular smears were obtained from the calves with clinically manifested keratoconjuctivitis and Moraxella bovis was isolated as the predominant bacterium, as well as P. Multocida, Streptococcus spp. and Nocardia spp. ${ }^{3,32}$ In the advanced gestation phase, the ringworm was established as a zoonosis which represents considerable problem from the point of view of the human health. The ringworm is a dermatomycosis caused by a fungus Trichophyton verrucosum and it develops mostly in calves and bullocks with lower physical condition and impaired immune response. The causative organism inhabits skin surface causing, through its proteolytic and catalytic enzymes as well as endotoxin, parakeratosis and inflammatory changes. The factors predisposing onset of the disease include increased air humidity, overcrowding of the facilities and inadequate feed quality. ${ }^{17}$

\section{Problems related to welfare and biosecurity in the ca- ttle production}

Given the numerous health problems listed calves and cattle, their welfare in intensive production is often called into question. Welfare of animals in terms of housing conditions often threaten inadequate ventilation, air velocity and air temperature, and exposure to pathogens and parasites. ${ }^{36}$ In addition to data on housing conditions, for a complete picture of the welfare state are taken to control the food and processes, such as for example power mode or rejection of calves. Analysis of potential risks to the welfare of a farmer indicates the possible causes for the present and other health problems in calves, as well as the problems that may arise in the future. ${ }^{15}$ Preventing disease in cattle also represent and protect their welfare. Relić et al..$^{37}$ discusses the importance of measurements of the biological safety of dairy cows on farms, in order to prevent introduction of infectious material or its dissemination at the farm. Tests were conducted biosecurity conditions on the farms of high-producing dairy cows of different production technology and capacity, considering the position of farms in relation to possible sources biorisk and distant environment. Test results indicated that in all tested farms there are serious shortcomings with regard to the possible introduction of infectious agents in the herd, and its possible spread to the environment. All studied farms were fenced, and the position of most farms was generally favorable. However, the problems were the lack of open space and green belt, uncontrolled presence of wild birds and rodents in facilities to keep cows and storing food, as well as contact employees with cows that do not belong to the farm which represents serious threat to health and livestock production farms. ${ }^{34}$

\section{Acknowledgements}

Research was financed by the Ministry of Education, Science and Technological Development Republic of Serbia project TR 31071.

\section{Conflict of interest}

Author declares that there is no conflict of interest.

\section{References}

1. Arthington JD, Cattel MB, Quigley JD. Effects of dietary IgG source (colostrum serum or milk derived supplement) on the efficiency if $\mathrm{Ig}$ absorbtion in newborn Holstein calves. J Dairy Sci. 2000;83:146-1467.

2. Basarić-Dinić LJ, Erski-Biljić M, Vuković D, et al. Ishrana krava muzara i stres. Simpozijum Mastitis i kvalitet mleka. Veterinarski glasnik. 1996;50(5-6):363-369.

3. Basarić-Dinić LJ, Cmiljanić R, Radojičić B. Nutritivna osnova stresa $\mathrm{u}$ intenzivnoj stočarskoj proizvodnji. Biotehnologija u stočarstvu. 1997;13(3-4):113-123.

4. Bojkovski J, Borozan S, Jožef I, et al. Colostrum ingredients before and after calving in Holstein-Frisian Cows. Veterinary Record 4. 2005; 156(23):744-745.

5. BojkovskI J, Borozan S. Temeraturne vrednosti visoko-mlečnih krava u puerperijumu. Savremena Poljoprivreda. 2007;56(3-4):75-79.

6. Bojkovski J, Djoković R, Borozan S, et al. Prilog poznavanju kliničke patologije buraga visoko-mlečnih krava. Savremena Poljoprivreda. 2007;56(3-4): 80-86.

7. Bojkovski J, Radojičić B, Petrujkić T, et al. A contribution to insight of the most important etiological factors with influence of farm animal health in Serbia. Proceedings of the International Symposium on new research in biotechnology. Seria: Bucharest, Romania, Biotehnology; 2008:101-114.

8. Bojkovski J, Savić B, Pavlović I, et al. The most common pathogenic causes of disease in dairy breed cattle and pigs in farm. Lucrări stiinłifice medicină veterinară Timisoara. 2011;XLIV(1):149-156. 
9. Bojkovski J, Pavlović I, Relić R, et al. Zdravstveni problemi i doborbit teladi u intenzivnoj proizvodnji Zbornik naučnih radova, Institut PKB, agroekonomik Beograd; 2012;18(3-4): 85-91.

10. Bojkovski J , Hadžić I, RogožarskI D, et al. Contribution to knowledge laminitis by dairy cows in serbia. Lucrări stiinłifice medicină veterinară. 2013;XLVII(4):24-32

11. Bojkovski J, Milanov D, Savić S, et al. Respiratory disease of calves on dairy cow farm. Bulltein UASVM Veterinry medicine. 2014;71(2):313-320.

12. Blum JW, Hardon V, Sallmann HP, et al. Delaying colostrums in take by one day impairs plasma lipid,essential fatty acid carotene retinol and $\alpha$ tocoferol status in neonatal calves. Journal of Nutrition. 1987;127(10):2024-2029.

13. Bugarski D, Lazic S, Petrović T, et al. Infekcije disajnih puteva teladi. Veterinarski Žurnal Republike Srpske. 2005;3-4:107-164.

14. Dieckmann MA, Green ML. Mycotoxins and reproduction in domestic livestock. J Anim Sci. 1992;70(5):1615-1627.

15. Dirksen G. Der Pansenazidose-Komplex- Neuere Erkenntnisse und Erfahrungen. Tierärztl Prax. 1985;13:501-512.

16. Čulinović M. Gnjiloća kože i papaka u goveda, izvor-Gospodarski list. 2010

17. Djoković R,Šamanc H, BojkovskI J, et al. Morfološko-funkcionalno stanje ćelija jetre kod mlečnih krava u ranoj laktaciji. Savremena poljoprivreda. 2007;56(3-4):92-97.

18. Djoković R, Šamanc H, Bojkovski J, et al. Blood concentrations of thyroid hormones and lipids of dairy cows in transitional period. Lucrări stiinłifice medicină veterinară. 2010;XLIII(2):34-40.

19. Djoković R, Giadinis N, Argiroudis S, et al. Zdravstvena zaštita preživara, Izdavač Agronomski fakultet u Čačku Univerziteta u Kragujevcu, udžbenik za studente Agronomskog fakulteta u Čačku. 2014.

20. Džigurski Lj, Bojkovski J, Radojičić B, et al. Prilog poznavanju infektivnog bovinog keratokonjunktivitisa u teladi 10. Godišnje savetovanje veterinara Republike Srpske. 2004. 68p.

21. Hadžić I, Pavlović I, Hudina V, et al. Dermatitis interdigitalis and dermatitis digitalis the great problem on cattle production. 2013.

22. Ivanov I, BojkovskI J, Jonić B. Neonatalna dijareja teladi. Zbornik predavanja XXII Seminara za inovacije znanja veterinara. Beograd; 1999:89-98 p.

23. Ivanov I, Janković D, Šamanc H, et al. Novi pristup terapiji i profilaks dijareje teladi. Treće savetovanje iz kliničke patologije i terapije životinja sa međunarodnim učešćem. Clinica veterinaria. 2001:137-141 p
24. Jovanović JM, Stamatović S, Šamanc H, et al. Prilog izučavanju metaboličkog profila krava u visokom graviditetu i puerperijumu. Veterinarski glasnik. 1987;41(5):343-349.

25. Krsmanović M, Đoković R, Bojkovski J. Deterimation of Characteristic Blood Organic Parameters in peripartal and peak Lactation Dairy Cows Bulltein USAVM. Veterinarinary Medicine. 2013;70(2):258-265

26. Metzner M. Update zur Dermatitis digitalis des Rindes. Großtierpraxis. 2001;2(6):47-51.

27. Nüske S. Die Häufibsten Erkran-Kungen der Rinderklave-Erkennung, Therapie und Prophylaxie aus Sicht des Kluenpfegers, Lehr und Versuchgut Oberschleibheim der Tierärztlich. München: Enfakultät der Ludwig-Maximilians Universität; 2007.

28. Ostojić Andrić D, Hristov S, et al. Dairy Cows Welfare Quality In Loose Vs. Tie Housing System. Biotechnology in Animal Husbandry. 2011;27(3):975-984

29. Petrujkić T, Petrujkić B, Bojkovski J, et al. Primena menadžmenta ishrane, zdravlja, proizvodnje i repordukcije mlečnih krava. Zbornik naučnih radova Instituta PKB Agroekonomik sa XXV Savetovanja Agronoma. Veterinara i Tehnologa. 2011:105-112 p.

30. Radojičić B, BojkovskI J, Petrujkić T, et al. Proizvodne bolesti viskokomlčenih krava. Biotehnology in Animal Husbandry. 2008;24:563-575.

31. Radojičić B, Bojkovski J, Jonić B, et al. Bolesti preživara, osnovni udžbenik. za studente Fakulteta veterinarske merdicine. Beograd; 2014.

32. Relić R, Bojkovski J. Housing conditions in calves welfare risk assessment. Journal of Agricultural Science. 2011;55(3):283-292.

33. Relić R, Hristov S, Stanković B, et al. Morović: Najznačajnije higijenske mere i biološka bezbednost na farmi mlečnih krava. Zbornik radova XVII Savetovanja Dezinfekcija, dezinsekcija $i$ deratizacija u zaštiti životne sredine. sa međunarodnim učešćem. 2006. p. 233-241.

34. Stanković BS, Hristov S, Bojkovski J, et al. The possibility of dairy farms isolation assessment - biosecurity aspect. Biotehnology in animal production. 2011;27(4):1425-1431.

35. Toholj B, Stevančević M, Milošević N, et al. Digitalni dermatitis kod muznih krava-faktori rizika, mogućnosti terapije i profilakse. Savremena poljoprivreda. 2008;57:3-4.

36. Zanker IA, Hamonn HM, Blum JW. Delayed feeding of first colostrum: are there prolonged effects on hematological, metabolic and endocrine parameters and growth performance in calves? J Anim Physiol Anim Nutr (Berl). 2001;85(3-4):53-66.

37. Zemljič B. Influence of foot bathing on prevalence of digital dermatitis after introduction of diseased animal into healthy dairy herd. Maribor, Slovenia: Proceedings of the $13^{\text {th }}$ International Symposium and $5^{\text {th }}$ Conference on Lameness in Ruminants. 2004. 